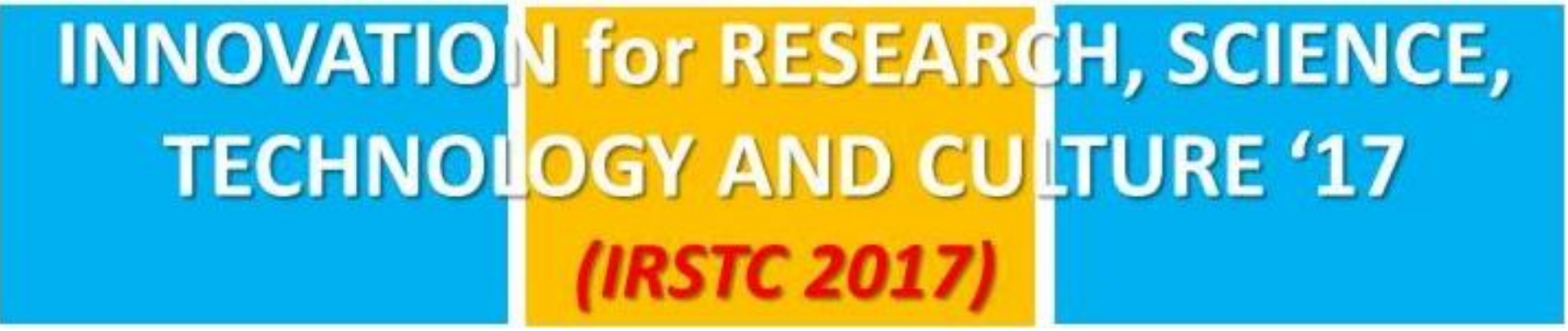

$4^{\text {th }}$ INTERNATIONAL SEMINAR: RESEARCH FOR SCIENCE, TECHNOLOGY AND CULTURE (IRSTC 2017)

\title{
Student Admission Assesment using Multi-Objective Optimization on the Basis of Ratio Analysis (MOORA)
}

\author{
Mesran ${ }^{1}$, Rivalri Kristianto Hondro², Muhammad Syahrizal ${ }^{3}$, Andysah Putera Utama Siahaan ${ }^{4}$, \\ Robbi Rahim ${ }^{5}$, Suginam 6 \\ ${ }^{1,2,3,6}$ Department of Informatics Engineering, STMIK Budi Darma, Medan, Indonesia \\ ${ }^{4}$ Faculty of Computer Science, Universitas Pembangunan Panca Budi, Medan, Indonesia \\ ${ }^{5}$ Department of Health Information, Akademi Perekam Medik dan Infokes Imelda, Medan, Indonesia \\ ${ }^{4,5}$ Student of Universiti Malaysia Perlis, Kangar, Malaysia
}

\begin{abstract}
Procurement selection process in the acceptance of prospective students is an initial step undertaken by private universities to attract superior students. However, sometimes this selection process is just a procedural process that is commonly done by universities without grouping prospective students from superior students into a class that is superior compared to other classes. To process the selection results can be done using the help of computer systems, known as decision support systems. To produce a better, accurate and objective decision result is used a method that can be applied in decision support systems. Multi-Objective Optimization Method by Ratio Analysis (MOORA) is one of the MADM methods that can perform calculations on the value of criteria of attributes (prospective students) that helps decision makers to produce the right decision in the form of students who enter into the category of prospective students superior.
\end{abstract}

Key-word: - Selection Student Excellence, Excellence Student Class, Decision Support System, MOORA

\section{Introduction}

Prospective students or students who will enter a college is a prospective product that will be produced by a college in four or five years to come. Before going into college, the first prospective student through the name of the process of admission of prospective students. The process of admission of prospective students to a private college is an early stage of learning conducted by a college. It is common to happen; a college receives many students who enter even though they have been through the selection process of acceptance. The results of the selection test are submitted to the students through the announcement, indicating the student is accepted or declared failed in the entrance examination selection process.

Many private universities do the above, the college entrance selection test, but exclude superior students or students who have enough value. It would be nice if the superior student is focused on one class compared to the students whose value is enough. This will also motivate students to be more active in learning because they are among students who have better skills compared to students who are not superior class.

In generating the information of superior class students, of course, through the terms and criteria set by the leadership of private universities. For the results to be decided better, of course through a series of the accurate assessment process, which is not only in the process by humans but also processed by the computer as a tool (Marlina et al. 2016) (Siahaan 2016). For this, it would be better to use a decision support system. Decision support system is a system intended for decision-makers in support of the resulting decisions. This system applies decision support methods applied in decision support systems. Many methods of decision support systems are developing today, such as the ELECTRE method that can measure the lecturer's performance index in generating the best lecturers' decisions in the computer (Mesran et al. 2017). There are also simple methods such as Weighted Sum Model (WSM), Simple Additive Weighting (SAW), Weighted Product (WP) or TOPSIS which is better at finding the ideal solution of some of the best decision alternatives (Jasri, Siregar, and Rahim 2017). 
From the previous research, that decision support system is a computer-based system that applies the method in solving the problem (Mesran et al. 2017)(Rahim et al. 2017)(Risawandi and Rahim 2016)(Haryati et al. 2016). Even in its application, this system can use fuzzy values for data can not be accurately measured or linguistic (Kusumadewi et al. 2006)(Perangin-angin et al. 2016).

In this research, the researcher uses Multi-Objective Optimization method on the basis of Ratio Analysis (MOORA). This method is also included in the MCDM section that is capable of performing the process simultaneously optimizing two or more conflicting attributes (goals) subject to certain limits (Karande and Chakraborty 2012). In its application, MCDM is divided into Multi-Attribute Decision Making (MADM) and Multi-Objective Decision Making (MODM). MADM is intended to solve the problem in a discrete space so that it requires several alternatives, criteria, and weights (Kusumadewi et al. 2006).

\section{Methodology}

\subsection{Decision Support System}

Decision support system is a computer-based system capable of solving management problems in generating the best alternative to support decisions made by decision makers (Turban, E., Aronson, J., \& Liang 2005).

2.2 Multi-Objective Optimization on The Basis of Ratio Analysis (MOORA)

A multi-objective (or programming) optimization, also known as a multicriteria or multiple attribute optimization, is the process of simultaneously optimizing two or more conflicting attributes (goals) subject to certain restrictions.

The MOORA method, first introduced by Brauers (2004) is a multiobjective optimization technique that can be successfully applied to solve various types of complex decision-making problems in a manufacturing environment.

Steps to completion of MOORA method(Karande and Chakraborty 2012)(Onur Önay and Yıldırım 2016):

Step 1: Create a Decision Matrix.

The decision matrix is represented as the $\mathrm{Xij}$ matrix, where $\mathrm{i}$ is, $\mathrm{m}$ that is the number of alternatives whereas $\mathrm{j}$ represents $\mathrm{n}$ in the number of criteria, equation 1 is the matrix representation of the decision.

$$
x=\left[\begin{array}{cccc}
x_{11} & x_{12} & \cdot & x_{1 n} \\
x_{21} & x_{22} & \cdot & x_{2 n} \\
\cdot & \cdot & \cdot & \cdot \\
x_{m 1} & x_{m 2} & \cdot & x_{m n}
\end{array}\right]
$$

Step 2: Normalize the Decision Matrix

Brauers (2008) concludes that for this denominator, the best option is the square root of the sum of squares of each alternative per attribute. This ratio can be expressed as follows:

$$
x_{i j}^{*}=x_{i j} / \sqrt{\left[\sum_{i=1}^{m} x_{i j}^{2}\right](j=1,2, \ldots, n)}
$$

Step 3: Optimize attributes.

For multi-objective optimization, these normalized performances are added in case of maximization (for favorable attributes) and reduced in case of minimization (for non-beneficial attributes). Then the optimization problem becomes:

$$
y_{i}=\sum_{j=1}^{g} x_{i j}^{*}-\sum_{j=g+1}^{n} x_{i j}^{*}
$$

Where $\mathrm{g}$ is the number of attributes to be maximized, (n-g) is the number of attributes to be minimized, and $\mathrm{y}_{\mathrm{i}}$ is the normalized value of the alternative value against all attributes. In some cases, it is often observed that some attributes are more important than others. In order to give more importance to the attribute, it can be multiplied by the corresponding weight (coefficient of significance).

When the weight of this attribute is considered, Eq. 3 being as follows:

$$
y_{i}=\sum_{j=1}^{g} w_{j} x_{i j}^{*}-\sum_{j=g+1}^{n} w_{j} x_{i j}^{*}(j=1,2, \ldots, n)
$$


Where $w_{j}$ is the weight of $j^{\text {th }}$ attribute, which can be determined applying an analytic hierarchy process (AHP) or an entropy method.

Step 4: The value of $\mathrm{y}_{\mathrm{i}}$ can be positive or negative depending on its maximal number (favorable attribute) and minimal (unfavorable attribute) in the decision matrix.

The ordinal rank of $y_{i}$ shows the final preference. Thus, the best alternative has the highest yi value, while the worst alternative has the lowest Yi value.

\section{Result and Discussion}

Process processes performed on Multi-Objective Optimization on The Basis of Ratio Analysis (MOORA) require criteria that affect participants (alternatives) in their calculations. Criteria (C) can be seen in the following table.

\section{TABLE I}

Criteria

\begin{tabular}{|c|l|c|c|}
\hline Criteria & Description & Weighted & Type \\
\hline C1 & UN Average Score & 0,25 & Benefit \\
\hline C2 & Psychotest Value & 0,15 & Benefit \\
\hline C3 & IPA Value & 0,20 & Benefit \\
\hline C4 & Mathematics Value & 0,20 & Benefit \\
\hline C5 & Interview Value & 0.20 & Benefit \\
\hline
\end{tabular}

Here are alternative match rating and criteria.

TABLE II

Alternative match rating and criteria

\begin{tabular}{|c|c|c|c|c|c|}
\hline Alternative & $\mathrm{C} 1$ & $\mathrm{C} 2$ & $\mathrm{C} 3$ & $\mathrm{C} 4$ & $\mathrm{C} 5$ \\
\hline $\mathrm{A}_{1}$ & 8.4 & 90 & 80 & 75 & 90 \\
\hline $\mathrm{A}_{2}$ & 7.3 & 89 & 80 & 70 & 80 \\
\hline $\mathrm{A}_{3}$ & 7.5 & 90 & 75 & 70 & 85 \\
\hline $\mathrm{A}_{4}$ & 8.0 & 85 & 85 & 60 & 90 \\
\hline $\mathrm{A}_{5}$ & 6.5 & 90 & 80 & 60 & 80 \\
\hline Optimum & Max & Max & Max & Max & Max \\
\hline
\end{tabular}

Here is the step of completion using MOORA:

From table 2, make the Xij decision matrix, as follows.

$x=\left[\begin{array}{lllll}8.4 & 90 & 80 & 75 & 90 \\ 7.3 & 89 & 80 & 70 & 80 \\ 7.5 & 90 & 75 & 70 & 85 \\ 8 & 85 & 85 & 60 & 90 \\ 6.5 & 90 & 80 & 60 & 80\end{array}\right]$

Then form a normalized matrix using equation 2 .

$$
\begin{gathered}
C_{1}=\sqrt{8.4^{2}+7.3^{2}+7.5^{2}+8^{2}+6.5^{2}} \\
=16.9 \\
A_{11}=8.4 / 16.9=0.4964 \\
A_{21}=7.3 / 16.9=0.4314 \\
A_{21}=7.5 / 16.9=0.4432
\end{gathered}
$$




$$
\begin{aligned}
& A_{21}=8 / 16.9=0.4728 \\
& A_{21}=6.5 / 16.9=0.3841 \\
& C_{2}=\sqrt{90^{2}+89^{2}+90^{2}+85^{2}+90^{2}} \\
& =198.6 \\
& A_{12}=90 / 198.6=0.4531 \\
& A_{22}=89 / 198.6=0.4481 \\
& A_{32}=90 / 198.6=0.4531 \\
& A_{42}=85 / 198.6=0.4280 \\
& A_{52}=90 / 198.6=0.4531 \\
& C_{3}=\sqrt{80^{2}+80^{2}+75^{2}+85^{2}+80^{2}} \\
& =179 \\
& A_{13}=80 / 179=0.4469 \\
& A_{23}=80 / 179=0.4469 \\
& A_{23}=75 / 179=0.4189 \\
& A_{23}=85 / 179=0.4748 \\
& A_{23}=80 / 179=0.4469 \\
& C_{4}=\sqrt{75^{2}+70^{2}+70^{2}+60^{2}+60^{2}} \\
& =150.4 \\
& A_{14}=75 / 150.4=0.4986 \\
& A_{24}=70 / 150.4=0.4654 \\
& A_{34}=70 / 150.4=0.4654 \\
& A_{44}=60 / 150.4=0.3989 \\
& A_{54}=60 / 150.4=0.3989 \\
& C_{5}=\sqrt{90^{2}+80^{2}+85^{2}+90^{2}+80^{2}} \\
& =190.3 \\
& A_{15}=90 / 190.3=0.4729 \\
& A_{25}=80 / 190.3=0.4203 \\
& A_{35}=85 / 190.3=0.4466 \\
& A_{45}=90 / 190.3=0.4729 \\
& A_{55}=80 / 190.3=0.4203
\end{aligned}
$$

The result of calculation is, the normalization matrix $\left(x_{i j}^{*}\right)$. 


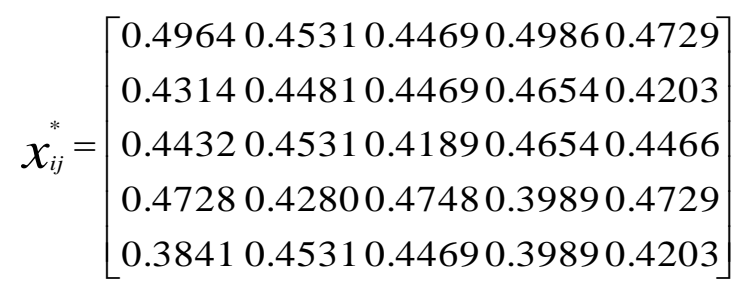

Then determine the value of yi using equation 4.

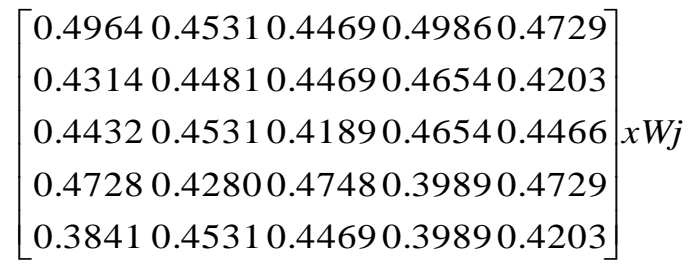

Results after calculated:

$$
\left[\begin{array}{lllll}
0.124 & 0.068 & 0.089 & 0.100 & 0.095 \\
0.108 & 0.067 & 0.089 & 0.093 & 0.084 \\
0.111 & 0.068 & 0.084 & 0.093 & 0.089 \\
0.118 & 0.064 & 0.095 & 0.080 & 0.095 \\
0.096 & 0.068 & 0.089 & 0.080 & 0.084
\end{array}\right]
$$

TABLE III

TABLE III
Y List
\begin{tabular}{|c|c|c|c|}
\hline Alternative & $\begin{array}{c}\text { Maximum } \\
\left(\mathrm{C}_{1}+\mathrm{C}_{2}+\mathrm{C}_{3}+\mathrm{C}_{4}+\mathrm{C}_{5}\right)\end{array}$ & $\begin{array}{c}\text { Minimum } \\
(0)\end{array}$ & $\begin{array}{c}\mathrm{Y}_{\mathrm{i}} \\
(\mathrm{Max}-\mathrm{Min})\end{array}$ \\
\hline $\mathrm{A}_{1}$ & 0.476 & 0 & 0.476 \\
\hline $\mathrm{A}_{2}$ & 0.442 & 0 & 0.442 \\
\hline $\mathrm{A}_{3}$ & 0.445 & 0 & 0.445 \\
\hline $\mathrm{A}_{4}$ & 0.452 & 0 & 0.452 \\
\hline $\mathrm{A}_{5}$ & 0.417 & 0 & 0.417 \\
\hline
\end{tabular}

Table 4 is a table of calculations that have been rank from the largest to the smallest.

TABLE IV

Results Rank

\begin{tabular}{|c|c|c|}
\hline Alternative & Results & Rank \\
\hline $\mathrm{A}_{1}$ & 0.476 & 1 \\
\hline $\mathrm{A}_{4}$ & 0.452 & 2 \\
\hline $\mathrm{A}_{3}$ & 0.445 & 3 \\
\hline $\mathrm{A}_{2}$ & 0.442 & 4 \\
\hline $\mathrm{A}_{5}$ & 0.417 & 5 \\
\hline
\end{tabular}

From the above calculation, it is concluded that alternative $\mathrm{A}_{1}$ is a new student candidate that has the greatest and acceptable value, while the A5 candidate may not be accepted.

\section{Conclusion}

From the explanation above it can be concluded that MOORA method one of the very simple MCDM implementation that can help decision makers produce a decision of the best of several alternatives 


\section{References}

Haryati, Sri, Ali Ikhwan, Diki Arisandi, Fadlina, and Andysah Putera Utama Siahaan. 2017. "Quality Assurance in Knowledge Data Warehouse." International Journal of Scientific Research in Science and Technology 239-242.

Jasri, Dodi Siregar, and Robbi Rahim. 2017. "Decision Support System Best Employee Assessments with Technique for Order of Preference by Similarity to Ideal Solution.” INTERNATIONAL JOURNAL OF RECENT TRENDS IN ENGINEERING \& RESEARCH 3(3): 6-17.

Karande, Prasad, and Shankar Chakraborty. 2012. "Application of Multi-Objective Optimization on the Basis of Ratio Analysis (MOORA) Method for Materials Selection." Materials and Design 37(2): 317-24.

Kusumadewi, Sri, Sri Hartati, Agus Harjoko, and Retantyo Wardoyo. 2006. Fuzzy Multi-Attribute Decision Making (Fuzzy $M A D M)$. Yogyakarta: Graha Ilmu.

Marlina, Leni, Muslim, and Andysah Putera Utama Siahaan. 2016. "Data Mining Classification Comparison (Naïve Bayes and C4.5 Algorithms)." International Journal of Engineering Trends and Technology 380-383.

Mesran, Garuda Ginting, Suginam, and Robbi Rahim. 2017. "Implementation of Elimination and Choice Expressing Reality ( ELECTRE ) Method in Selecting the Best Lecturer ( Case Study STMIK BUDI DARMA )." International Journal of Engineering Research \& Technology (IJERT 6(2): 141-44. http://www.ijert.org/view-pdf/16277/implementation-ofelimination-and-choice-expressing-reality-electre-method-in-selecting-the-best-lecturer-case-study-stmik-budi-darma.

Onur Önay, and Bahadır Fatih Yıldırım. 2016. "Evaluation of NUTS Level 2 Regions of Turkey by TOPSIS , MOORA and VIKOR 1." International Journal of Humanities and Social Science 6(1): 212-21.

Perangin-angin, Mochammad Iswan et al. 2016. "Tuition Reduction Determination Using Fuzzy Tsukamoto." International Journal of Engineering Science Invention 5(9): 68-72. http://www.ijesi.org/papers/Vol(5)9/M05906872.pdf.

Siahaan, A. P. 2016. "Fuzzification of College Adviser Proficiency Based on Specific Knowledge." International Journal of Advanced Research in Computer Science and Software Engineering, 6(7), 164-168.

Rahim, Robbi, Mesran, Andysah Putera Utama Siahaan, and Solly Aryza. 2017. "Composite Performance Index for Student Admission." International Journal of Research In Science \& Engineering 3(3).

Risawandi, and Robbi Rahim. 2016. "Study of the Simple Multi-Attribute Rating Technique For Decision Support." IJSRST 2(6): 491-94.

Turban, E., Aronson, J., \& Liang, T.-P. 2005. Decision Support Systems And Inteligence System. US: Prentice-Hall. 